\title{
PENGARUH TEKNIK COOPERATIVE LEARNING DAN BERPIKIR KRITIS TERHADAP HASIL BELAJAR IPS
}

\author{
Heru Yuono \\ Mahasiswa S2 Pendidikan Dasar UNJ \\ yuonoh@yahoo.co.id
}

\begin{abstract}
This study aimed to find out and analyze the effect of Numbered Heads Together (NHT) and Teams Games Tournament (TGT) technique cooperative learning and critical thinking ability on students' learning achievement in Social Science. This study was conducted at SDN Ciwaruga 1 at Parongpong district in West Bandung with factorial experiment treatment by level $2 \times 2$ design. The sample of this study as many as 44 students was selected by random sampling technique. Data analysis took $27 \%$ of upper group and lower group and used two path variance analysis with $\mathrm{F}$ test followed by Tukey test. The result of the study shows as follows: (1) as a whole, students' learning achievement with NHT technique cooperative learning is higher than TGT technique cooperative learning with $\mathrm{F}$ test $=5.539$ showing that it is statistically significant at the 0.05 level; (2) for high critical thinking ability students, students' learning achievement with NHT technique cooperative learning is higher than TGT technique cooperative learning with $t$ test $=12.22$ showing that it is statistically significant at the 0.05 level; (3) for low critical thinking ability students, students' learning achievement with TGT technique cooperative learning is higher than NHT technique cooperative learning with $\mathrm{t}$ test $=5.55$ showing that it is statistically significant at the 0.05 level; (4) there is an interaction effect between the use of cooperative learning and students' critical thinking ability with $\mathrm{F}$ test $=39.38$ that it is statistically significant at the 0.05 level. It can be concluded that the effect of NHT and TGT technique cooperative learning and critical thinking ability on students' learning achievement in Social Science at SDN Ciwaruga 1 at Parongpong district in West Bandung.
\end{abstract}

Key Words: Numbered Head Together, Teams Games Tournament, Cooperative Learning, Critical Thinking Ability, Students' Learning Achievement.

\begin{abstract}
Abstrak: Penelitian ini bertujuan untuk mengetahui dan menganalisis pengaruh Numbered Heads Together (NHT) dan Teams Games Tournament teknik (TGT) pembelajaran kooperatif dan kemampuan berpikir kritis terhadap prestasi belajar siswa dalam IPS. Penelitian ini dilakukan di SDN Ciwaruga 1 di Kecamatan Parongpong di Bandung Barat dengan pengobatan percobaan faktorial dengan desain tingkat $2 \times 2$. Sampel penelitian ini sebanyak 44 siswa terpilih dengan teknik random sampling. Analisis data mengambil 27\% dari kelompok atas dan kelompok bawah dan menggunakan dua analisis varians jalur dengan uji $\mathrm{F}$ dilanjutkan dengan uji Tukey. Hasil penelitian menunjukkan sebagai berikut: (1) secara keseluruhan, prestasi belajar siswa dengan teknik NHT pembelajaran kooperatif lebih tinggi dari TGT teknik pembelajaran kooperatif dengan uji $\mathrm{F}=5,539$ menunjukkan bahwa secara statistik signifikan pada tingkat 0,05 ; (2) untuk kritis yang tinggi siswa kemampuan berpikir, hasil belajar siswa dengan teknik NHT pembelajaran kooperatif lebih tinggi daripada teknik TGT pembelajaran kooperatif dengan uji $t=$ 12,22 menunjukkan bahwa secara statistik signifikan pada tingkat 0,05 ; (3) untuk siswa kemampuan berpikir kritis rendah, prestasi belajar siswa dengan teknik TGT pembelajaran kooperatif lebih tinggi daripada teknik NHT pembelajaran kooperatif dengan uji $\mathrm{t}=5,55$ menunjukkan bahwa secara statistik signifikan pada tingkat 0,$05 ;(4)$ ada pengaruh interaksi antara penggunaan pembelajaran kooperatif dan kemampuan berpikir kritis siswa dengan uji $\mathrm{F}=39,38$ bahwa itu adalah statistik signifikan pada tingkat 0,05. Dapat disimpulkan bahwa efek NHT dan TGT teknik pembelajaran kooperatif dan kemampuan berpikir kritis terhadap prestasi belajar siswa dalamIPS di SDN Ciwaruga 1 di Kecamatan Parongpong di Bandung Barat.
\end{abstract}

Kata kunci: Numbered Head Together, Teams Games Tournament, Pembelajaran Kooperatif, Kritis Kemampuan Berpikir, Prestasi Belajar Siswa. 
Peningkatan kualitas pendidikan pada semua jenjang pendidikan di sekolah merupakan salah satu upaya peningkatan kualitas pendidikan di Indonesia. Peningkatan kualitas pendidikan di sekolah berkaitan erat dengan kualitas proses belajar mengajar yang dilakukan guru dan siswa di sekolah. Proses belajar mengajar pada hakikatnya merupakan kegiatan interaksi antara dua unsur manusiawi, yakni siswa sebagai pihak yang belajar dan guru sebagai pihak yang mengajar, dengan siswa sebagai subjek pokoknya. Sebagai konsekuensi bahwa siswa merupakan sentral, maka aktivitas siswa merupakan syarat mutlak bagi berlangsungnya interaksi belajar mengajar, baik aktif fisik maupun aktif mental.

Berdasarkan hasil observasi dan wawancara peneliti di SDN Ciwaruga $1 \mathrm{Kec}$. Parongpong Bandung Barat, bahwa nilai ratarata mata pelajaran IPS di kelas $\mathrm{V}$ pada semester genap untuk tahun ajaran 2013/2014 mencapai 55. Hasil ini belum mencapai KKM yang ditentukan yaitu 60. Rendahnya hasil belajar IPS disebabkan oleh kesulitankesulitan belajar yang dialami siswa pada setiap materi pelajaran.

Teknik pembelajaran adalah salah satu faktor yang menyebabkan rendahnya hasil belajar siswa. Berdasarkan temuan di lapangan, para siswa kurang bergairah atau bersikap acuh pada mata pelajaran yang diberikan oleh guru tersebut, apabila Teknik pembelajaran tersebut tidak sesuai dengan karakteristik materi pelajaran yang diajarkan kepada siswa. Selama ini sekolah tersebut hanya menggunakan treknik pembelajaran yang terpusat pada guru (teacher centre) saja sehingga pembelajaran terasa membosankan dan siswa tidak terlibat secara aktif dalam proses pembelajaran.

Terdapat berbagai macam teknik pembelajaran yang dapat digunakan guru di kelas, salah satu diantaranya adalah teknik pembelajaran kooperatif. Namun perlu disadari bahwa teknik tersebut tidak ada yang terbaik dan terburuk, karena masing-masing teknik pembelajaran memiliki kelebihan dan kekurangan.

Teknik pembelajaran yang dapat dianggap cocok dan memenuhi syarat untuk mencapai tujuan tersebut adalah teknik pembelajaran kooperatif Numbered Heads Together (NHT) dan Teams Games Tournament (TGT). Dengan teknik tersebut maka peran guru dalam pembelajaran lebih memungkinkan terciptanya kondisi belajar yang lebih kondusif seperti memberikan kesempatan kepada siswa untuk berperan lebih aktif bertukar informasi dalam kelompok, berpikir kritis, dan bertanggung jawab.

Dalam peroses pembelajaran seorang siswa biasanya memiliki keterampilan berpikir kritis yang berbeda, dimana faktor-faktor tersebut menunjukan kemampuan seseorang dalam 
Pengaruh Teknik Cooperative Learning Dan

Berpikir Kritis Terhadap Hasil Belajar IPS

Heru Youno

berkomusikasi, berfikir dan menyelesaikan masalah.

Kemampuan berpikir kritis yang berbeda pada masing-masing siswa tentu mempengaruhi penyerapan pelajaran demikian pula halnya dengan teknik pembelajaran yang diterapkan guru. Siswa yang memiliki Kemampuan berpikir kritis tinggi dan Kemampuan berpikir kritis rendah akan mendominasi pada pembelajaran kooperatif. Dengan demikian teknik pembelajaran Numbered Heads Together (NHT) dan Teams Games Tournament (TGT) diharapkan menjadi solusi yang menarik untuk dipraktikkan di ruang-ruang kelas dalam rangka meminimalkan berbagai hambatan belajar siswa ketika teknik pembelajaran yang kurang menyenangkan cenderung hanya berasosiasi pada satu jenis modalitas belajar saja.

Penelitian ini bertujuan untuk mendapatkan data emperis tentang perbedaan hasil belajar IPS siswa yang disebabkan oleh pengaruh teknik pembelajaran kooperatif $N H T$ dan TGT. Secara khusus tujuan penelitian ini adalah sebagai berikut : 1) untuk mengetahui perbedaan Hasil belajar IPS siswa yang diajarkan dengan menggunakan teknik pembelajaran Numbered Heads Together (NHT) dengan teknik pembelajaaran Teams Games Tournament (TGT). 2) Untuk mengetahui pengaruh interaksi antara teknik pembelajaran kooperatif terhadap hasil belajar
IPS. 3) Untuk mengetahui perbedaan hasil belajar IPS antara siswa yang diajarkan dengan teknik pembelajaran Numbered Heads Together (NHT) yang memiliki kemampuan berpikir kritis tinggi dan siswa yang diajarkan dengan teknik pembelajaran Teams Games Tournament (TGT) yang memiliki kemampuan berpikir kritis tinggi. 4) untuk mengetahui perbedaan hasil belajar IPS antara siswa yang diajarkan dengan teknik pembelajaran Numbered Heads Together (NHT) yang memiliki kemampuan berpikir kritis rendah dan siswa yang diajarkan dengan teknik pembelajaran Teams Games Tournament (TGT) yang memiliki kemampuan berpikir kritis rendah.

secara praktis manfaat penelitian ini adalah sebagai sumbangan pemikiran bagi guru dalam merancang proses pembelajaran agar diperoleh hasil yang optimal dalam meningkatkan hasil belajar siswa, dalam hal ini mutu pendidikan, khususnya dalam mata pelajaran IPS. Penelitian ini juga dapat memberikan masukan kepada siswa mengenai cara belajar yang baik, efesien sehingga dapat meningkatkan hasil belajar IPS.

Secara teoretis manfaat penelitian ini adalah untuk menambah wawasan tentang penggunan teknik pembelajaran Numbered Heads Together (NHT), teknik pembelajaran teams games tournament (TGT), kemampuan berpikir kritis dan hasil belajar IPS 
Menurut Nana Sudjana (2009 : 3) hasil belajar siswa pada hakikatnya adalah perubahan tingkah laku yang telah terjadi melalui proses pembelajaran. Perubahan tingkah laku tersebut berupa kemampuankemapuan siswa setelah aktivitas belajar yang menjadi hasil perolehan belajar. Dengan demikian hasil belajar adalah perubahan yang terjadi pada individu setelah mengalami pembelajaran.

Oemar Hamalik, (2002 : 155) Hasil belajar tampak sebagai terjadinya perubahan tingkah laku pada diri siswa, yang dapat diamati dan diukur dalam perubahan pengetahuan, sikap, dan keterampilan.

Sementara itu, Howard (dalam Sudjana 2009 : 22) membagi 3 macam hasil belajar yaitu, keterampilan dan kebiasaan, pengetahuan dan pengertian serta sikap dan cita-cita. Pendapat dari Horward Kingsley ini menunjukkan hasil perubahan dari semua proses belajar. Hasil belajar ini akan melekat terus pada diri siswa karena sudah menjadi bagian dalam kehidupan siswa tersebut.

Kurikulum KTSP menyatakan bahwa IPS merupakan salah satu mata pelajaran yang diberikan mulai dari

\section{SD/MI/SDLB/SMP/MTs/SMPLB.IPS}

mengkaji seperangkat ilmu sosial pada jenjang SD/MI pada jenjang mata pelajaran IPS memuat materi geografi, sejarah, sosiologi, dan ekonomi. melalui mata pelajaran IPS, siswa diarahkan untuk dapat menjadi warga negara yang demokratis dan bertanggungjawab serta warga dunia yang cinta damai, (Depdiknas, 2007 : 140)

Berkaitan dengan IPS, Sumantri (2001: 3) menyatakan bahwa Pendidikan IPS adalah penyederhanaan atau adaptasi dari disiplin ilmu-ilmu sosial dan humaniora, serta kegiatan dasar manusia yang diorganisasikan dan dikaji secara ilmiah dan pedagogis atau psikologis untuk tujuan pendidikan.

Sebagai bidang ajar di sekolah, IPS memiliki tujuan untuk mengembangkan pengetahuan, sikap, dan keterampilan sosial dalam bentuk konsep dan pengalaman belajar yang dipilih atau diorganisasikan dalam rangka kajian ilmu sosial. Berkaitan dengan tujuan IPS, KTSP 2006 menjelaskan tentang tujuan IPS sebagai berikut:

(a) Mengenal konsep-konsep yang berkaitan dengan kehidupan masyarakat dan lingkungannya; (b) Memiliki kemampuan dasar untuk berpikir logis dan kritis,rasa ingin tahu,inkuiri, memecahkan masalah, dan keterampilan dalam kehidupan sosial; (c) Memiliki komitmen dan kesadaran terhadap nilai-nilai sosial dan kemanusiaan; (d) Memiliki kemampuan

berkomonikasi, bekerjasama dan berkompetisi dalam masyarakat yang majemuk, ditingkat lokal, nasional, dan global. (Depdiknas, 2007 : 140) 
Pengaruh Teknik Cooperative Learning Dan

Berpikir Kritis Terhadap Hasil Belajar IPS

Heru Youno

Untuk mencapai tujuan-tujuan IPS SD yang telah dikemukakan di atas, maka diperlukan keterampilan proses dimana telah diketahui bahwa keterampilan proses dapat memungkinkan siswa untuk memproses informasi baru memalui pengalaman.

Theresia (2009: 27-28) mengemukakan bahwa ada tujuh aspek keterampilan proses yang dapat dinilai. Diantaranya: (1) Mengamati, melihat, mendengar, meraba dan merasakan dengan kulit, mencium, membaui, menyimak, mencicipi, mengukur dan membaca (2) Mengklasifikasikan, mencari persamaan, membandingkan, mengkontraskan, mencari perbedaan, mencari dasar pengelolaan. (3) Menginterpretasikan, menaksirkan, menemukan pola, menemukan arti atau mengartikan, mencari hubungan ruang dan waktu, menarik kesimpilan, menggeneralisasikan. (4) Memprediksi (meramalkan), mengantisipasikan

(berdasarkan kecenderungan, pola, hubungan antar data, atau informasi). (5) Menerapkan, menggunakan informasi, kesimpulan, konsep, hokum teori, nilai, sikap atau keterampilan dalam situasi baru, menghitung, membuat model, menentukan variable, menyusun hipotesis, mengendalikan variabel, menghubungkan konsep, merumuskan pertanyaan penelitian. (6) Merencanakan (penelitian), menentukan masalah atau objek yang akan diteliti, menentukan tujuan penelitian, menentukan ruang lingkup penelitian, menentukan sumber data, menentukan alat, beban dan sumber perpustakaan, menentukan cara melakukan penelitian. (7) Mengkomunikasikan, bisa berdiskusi, mendeklamasikan, mendramakan, bertanya, mengarang, merenungkan, mengerjakan, mengungkapkan dan melaporkan dalam bentuk lisan, tulisan, gambar, gerak, atau penampilan.

Cara pengukuran keterampilan proses ini dapat diukur melalui cara tes dan non tes. Cara non tes dilakukan dengan menggunakan lembar observasi sedangkan tes, pengukuran dilakukan dengan menggunakan tes tertulis dan tes perbuatan.

Berdasarkan penjelasan-penjelasan di atas, dapat disimpulkan bahwa Hasil belajar Ilmu Pengetahuan Sosial (IPS) merupakan hasil optimal yang diperoleh siswa setelah memperlajari IPS dengan jalan mencari berbagai informasi yang dibutuhkan sehingga siswa tersebut mampu memecahkan masalah yang berkaitan dengan masalah sosial dan menerapkannya dalam kehidupan masyarakat. Dalam penelitian ini, hasil belajar IPS mengacu pada indikator keterampilan proses, yaitu; (1) mengamati, (2) mengklasifikasi, (3) menginterpretasi, (4) menganalisis, menerapkan, (6) memprediksi, dan (7) mengkomunikasikan tentang pengetahuan sosial. 


\section{Kemampuan berpikir kritis}

Fahruddin Faiz (2012: 3) Berpikir kritis merupakan aktivitas mental yang dilakukan untuk mengevaluasi kebenaran sebuah pernyataan.Umumnya evaluasi berakhir dengan putusan untuk menerima, menyangkal, atau meragukan kebenaran pernyataan yang dimaksud.

Menurut Desmita (2013: 153) berpikir kritis adalah kemampuan untuk berpikir secara logis, reflektif, dan produktif yang diaplikasikandalam menilai situasi untuk membuat pertimbangan dan keputusan yang baik.

Menurut Edward Glaser (dalam Fisher 2004: 4) keterampilan-keterampilan berpikir sebagai landasan untuk berpikir kritis diantaranya mempunyai kemampuan untuk: (1) Mengenal masalah, (2) Menemukan caracara yang dapat dipakai untuk menangani masalah-masalah itu, (3) Mengumpulkan dan menyusun informasi yang diperlukan, (4) Mengenal asumsi-asumsi dan nilai-nilai yang tidak dinyatakan, (5) Memahami dan menggunakan bahasa yang tepat, jelas, dan khas, (6) Menganalisis data, (7) Menilai fakta dan mengevaluasi pernyataan-pernyataan, (8) Mengenal adanya hubungan yang logis antara masalah-masalah, (9) Menarik kesimpulankesimpulan dan kesamaan-kesamaan yang diperlukan, (10) Menguji kesamaan-kesamaan dan kesimpulan-kesimpulan yang seseoran ambil, (11) Menyusun kembali pola-pola keyakinan seseoran berdasarkan pengalaman yang lebih luas, (12) Membuat penilaian yang tepat tentang hal-hal dan kualitas-kualitas tertentu dalam kehidupan sehari-hari

Siswa dapat dikatakan memiliki kemampuan berpikir kritis apabila memenuhi indikator sebagai berikut;(1) mengidentifikasi suatu masalah sehingga mampu menemukan sebab-sebab kejadian/peristiwa, (2) berpikir logis, (3) menilai dampak dari kejadian peristiwa, (4) merancang sebuah solusi berdasarkan masalah, dan (5) menarik kesimpulan.

\section{Teknik Pembelajarn Kooperatif}

Menurut Nurhadi (2003: 60) teknik pembelajaran kooperatif adalah suatu sistem yang didasarkan pada alasan bahwa manusia sebagai makhluk individu yang berbeda satu sama lain sehingga konsekuensi logisnya manusia harus menjadi makhluk sosial, makhluk yang berinteraksi dengan sesama.

Menurut Rusman (2010: 202) teknik pembelajaran kooperatif (Cooperative learning) merupakan Bentuk pembelajaran dengan cara siswa belajar dan bekerja dalam kelompok-kelompok kecil secara kolaboratif yang anggotanya terdiri dari empat sampai enam orang dengan struktur kelompok yang bersifat heterogen.

Sejalan dengan pemikiran tersebut, Isjoni (2009: 15) mengatakan bahwa pembelajaran 
Pengaruh Teknik Cooperative Learning Dan

Berpikir Kritis Terhadap Hasil Belajar IPS

Heru Youno

Kooperatif adalah suatu teknik pembelajaran dimana siswa belajar dan bekerja dalam kelompok-kelompok kecil siswa kolaboratif yang anggotanya 4-6 orang dengan struktur kelompok heterogen.

Inti dari pembelajaran kooperatif adalah konsep sinergi, yakni energi atau tenaga yang terhimpun melalui kerjasama sebagai salah satu fenomena kehidupan masyarakat, (Syaiful Sagala 2010: 177).

\section{Teknik Pembelajaran Numbered Heads Together (NHT)}

Pembelajaran dengan menggunakan teknik Numbered Heads Together diawali dengan numbering. Guru membagi kelas menjadi kelompok-kelompok kecil. Setiap anggota kelompok diberi nomor sesuai dengan jumlah anggota kelompok. Setelah terbentuk kelompok, maka guru mengajukan pertanyaan yang harus dijawab oleh setiap kelompok, selanjutnya guru memberikan kesempatan kepada masing-masing kelompok untuk menyatukan kepalanya "Heads Together" berdiskusi memikirkan jawaban atas pertanyaan guru, (Agus Suprijono 2011: 92)

Pelaksanaan pembelajaran dengan teknik pembelajaran kooperatif teknik NHT diantaranya: 1) siswa dibagi dalam kelompok, setiap siswa dalam setiap kelompok mendapatkan nomor, 2) guru memberikan tugas dan masing-masing kelompok mengerjakannya, 3) kelompok memutuskan jawaban yang dianggap paling benar dan memastikan setiap anggota kelompok mengetahui jawaban tersebut, 4) guru memanggil salah satu nomor, siswa dengan nomor yang dipanggil melaporkan hasil kerjasama mereka, (Trianto, 2009: 67)

\section{Teknik Pembelajaran Teams Games}

\section{Tournament (TGT)}

Menurut Mohamad Nur (2011: 40) salah satu teknik pembelajaran kooperatif adalah Teams Games Tournament yang merupakan teknik pembelajaran yang menggunakan turnamen pembelajaran akademik. Dalam turnemen itu siswa bertanding mewakili timnya dengan anggota tim lain yang setara dalam kinerja akademik mereka yang lalu.

Isjoni (2009: 83-84) menjelaskan bahwa $T G T$ adalah salah satu teknik pembelajaran kooperatif yang menempatkan siswa dalam kelompok-kelompok belajar yang beranggotakan 5 sampai 6 orang siswa yang memiliki kemampuan, jenis kelamin, dan suku atau ras yang berbeda.

Dalam Teams Games Tournaments (TGT) siswa memainkan permainan dengan anggotaanggota tim lain untuk memperoleh skor bagi tim mereka masing-masing. Permainan dapat disusun guru dalam bentuk kuis berupa pertanyaan-pertanyaan yang berkaitan dengan materi pelajaran.Kadang-kadang dapat juga diselingi dengan pertanyaan yang berkaitan 
dengan kelompok (identitas kelompok mereka), (Rusman, 2010: 224)

Menurut Slavin (2010: 166) pembelajaran kooperatif teknik $T G T$ terdiri dari 5 langkah tahapan yaitu: Presentasi di kelas, tim (teams), permainan (games), pertandingan (tournaments), dan perhargaan kelompok ( team recognition).

\section{METODE}

Penelitian ini menggunakan desain penelitian Treatment by level yang merupakan pengembangan dari true eksperiment design yaitu dengan memperhatikan kemungkinan adanya variabel moderator yang mempengaruhi perlakuan (variabel independen) terhadap hasil (variabel dependen).

Adapun desain penelitian ini menggunakan faktorial 2X2 yang terdapat tiga variabel penelitian, variabel penelitian ini terdiri dari satu variabel bebas dan satu variabel moderator, variabel bebas adalah teknik pembelajaran yang terdiri dari Teknik pembelajaran Numbered Heads Together (NHT) $\left(\mathrm{A}_{1}\right)$ dan Teknik pembelajaran Teams Games Tournament (TGT) $\left(\mathrm{A}_{2}\right)$. Sedangkan variabel moderator pada penelitian ini adalah Kemampuan Berpikir kritis yang terdiri dari Kemampuan Berpikir kritistinggi $\left(B_{1}\right)$ dan Kemampuan Berpikir kritisrendah $\left(\mathrm{B}_{2}\right)$. Sedangkan variabel terikat adalah hasil belajar IPS. populasi dalam penelitian ini adalah seluruh siswa kelas V SDN Ciwaruga Kab. Bandung Barat tahun ajaran 2013-2014

Pengambilan sampel dilakukan secara Simple random sampling dengan tahapan sebagai berikut; (1) Menentukan 2 kelas eksperimen dengan pertimbangan dua kelas tersebut memiliki karakteristik yang sama, baik dari segi kemampuan siswa ataupun jenis kelamin sehingga populasinya homogen.(2) Menentukansiswa kelas VA dan siswa kelas VB SDN Ciwaruga $1 \mathrm{Kec}$. Parongpong Kab. Bandung Barat sebagai kelas penelitian, dimana jumlah siswa pada masing-masing kelas penelitian tersebut adalah 22 siswa. (3) Memilih kelas VA SDN Ciwaruga $1 \mathrm{Kec}$. Parongpong Kab. Bandung Barat sebagai kelas eksperimen 1 dan kelas VB SDN Ciwaruga 1 Kec. Parongpong Kab.Bandung Barat sebagai kelas eksperimen 2. (4) kemudian kelas eksperimen 1 dan kelas eksperimen 2 dilakukan tes untuk mengetahui kemampuan berpikir kritis tinggi dan rendah, selanjutnya skor yang diperoleh dari tes tersebut diperingkatkan dari skor tertinggi hingga skor terendah, kemudian diambil sebanyak 27\% kelompok atas yang dinyatakan sebagai kelompok berpikir kritis tinggi dan $27 \%$ kelompok bawah yang dinyatakan sebagai kelompok berpikir kritis rendah. Pengambilan masing-masing $27 \%$ kelompok atas dan bawah. 
Pengaruh Teknik Cooperative Learning Dan Berpikir Kritis Terhadap Hasil Belajar IPS Heru Youno

\section{HASIL}

Statistik deskriptif hasil penelitian dianalisis dengan menggunakan statistik deskriptif dan statistic iferensial pada enam kelompok.

Pengujian hipotesis dalam penelitian ini menggunakan analisis varians (ANAVA) dua jalur, namun terlebih dahulu dilakukan uji persyaratan analisis data yakni uji normalitas data dan uji homogenitas data. pengujian normalitas pada penelitian ini dilakukan terhadap enam kelompok skor hasil belajar IPS yaitu: Pengujian normalitas data ini dilakukan melalui uji Lilifirs dengan $\alpha=0.5$. pengujian normalitas pada penelitian ini dilakukan pada enam kelompok skor hasil belajar IPS yaitu: (A1) Kelompok siswa yang diajarkan menggunakan teknik pembelajaran NHT; (A2)Kelompok siswa yang diajarkan menggunakan teknik pembelajaran $T G T$; (A1B1) Kelompok siswa yang diajarkan dengan menggunakan teknik pembelajaran NHT dan siswa yang memiliki kemampuan Berpikir kritis tinggi; (A2B1) Kelompok siswa yang diajarkan menggunakan teknik pembelajaran $T G T$ dan siswa yang memeiliki kemampuan Berpikir kritis tinggi; (A1B2) Kelompok siswa yang diajarkan teknik pembelajaran NHT dan siswa yang memiliki memeiliki kemampuan Berpikir kritis rendah; (A2B2) Kelompok siswa yang diajarkan menggunakan teknik pembelajaran $T G T$ dan siswa yang memiliki kemampuan Berpikir kritis rendah.

Rekapitulasi Hasil Uji Normalitas Data Hasil Belajar IPS kelas V

\begin{tabular}{ccccc} 
No. & Kelompok & LHitung & Ltabel & Kesimpulan \\
\hline 1 & A1 & 0.139 & 0,242 & Normal \\
\hline 2 & A2 & 0.046 & 0,242 & Normal \\
\hline 3 & A1B1 & 0.055 & 0,319 & Normal \\
\hline 4 & A1B2 & 0.049 & 0,319 & Normal \\
\hline 5 & A2B1 & 0.000 & 0,319 & Normal \\
\hline 6 & A2B2 & 0.0007 & 0,319 & Normal
\end{tabular}

Dalam penelitian ini uji homogenitas varians dilakukan terhadap beberapa kelompok yaitu: a) uji homogenitas hasil belajar A1 dan A1 dengan uji F. setelah dilakukakan perhitungan, diperoleh Fhitung sebesar 3.60 sedangkan $\mathrm{F}$ table 3.84. jadi kesimpulannya adalah Ho diterima karena Fhitung $<$ Ftabel artinya kedua kelompok data yang diuji adalah homogen. b) uji homogenitas varians pada dua kelompok B1 dan B2 dengan uji F. setelah dilakukakan perhitungan, diperoleh Fhitung sebesar 191 sedangkan Ftable 3.84, jadi kesimpulannya adalah Ho diterima karena Fhitung $<$ Ftabel artinya kedua kelompok data yang diuji adalah homogen. c) uji homogenitas hasil Belajar IPS pada empat kelompok 
interaksi perlakuan dan atribut, yaitu A1B1, signifikan 0.05. adapun hasil analisis uji A1B2, A2B1, A2B2 dilakukan dengan homogenitas uji bartlet dapat dilihat pada table menggunakan uji bartlett dengan taraf dibawah ini:

\begin{tabular}{ccccc} 
Kelompok Sampel & $\mathbf{d b}$ & $\mathbf{S}^{\mathbf{2}}$ & $\mathbf{l o g} \mathbf{s}^{\mathbf{2}}$ & $\mathbf{d b}^{*} \operatorname{logs} \mathbf{s}^{\mathbf{2}}$ \\
\hline A1B1 & 5 & 20.73 & 1.316599 & 6.5829 \\
\hline A1B2 & 5 & 31.10 & 1.49276 & 7.4638 \\
\hline A2B1 & 5 & 57.79 & 1.761853 & 8.8093 \\
\hline A2B2 & 5 & 92.95 & 1.968249 & 9.8412 \\
\hline & 20 & 202.57 & - & 32.6973
\end{tabular}

Kesimpulan: berdasarkan hasil perhitungan di atas diperoleh harga $X^{2}$ Chi-kuadrat adalah 0.4038 untuk $\alpha=0.05$ dengan $\mathrm{dk}=\mathrm{k}-1=4-1$ $=3$ maka xtabel $=7.82$. karena $X$ hitung $<X$ table $=1.302<7.82$ maka Ho diterima. Jadi keempat data sampel di atas berasal dari populasi yang homogeny
Pengujian hipotesis penelitian ini dilakuakan dengan teknik analisis varians (ANAVA 2X2) dengan menggunakan SPSS. Adapun hasil ringkasannya adalah sebagai berikut:

\section{Tests of Between-Subjects Effects}

\section{Dependent Variable:Hasil Belajar IPS}

\begin{tabular}{lrrrrrr} 
Source & $\begin{array}{c}\text { Type III Sum } \\
\text { of Squares }\end{array}$ & df & $\begin{array}{c}\text { Mean } \\
\text { Square }\end{array}$ & F & Sig. & \multicolumn{2}{c}{$\begin{array}{c}\text { Partial Eta } \\
\text { Squared }\end{array}$} \\
\hline Corrected Model & $2762.726^{\mathrm{a}}$ & 3 & 920.909 & 19.127 & .000 & .742 \\
\hline Intercept & 119472.193 & 1 & $\begin{array}{r}119472.1 \\
93\end{array}$ & 2481.383 & .000 & .992 \\
\hline Teknik Pemb.Kooperatif & 266.667 & 1 & 266.667 & 5.539 & .029 & .217 \\
\hline Berpikir Kritis & 600.000 & 1 & 600.000 & 12.462 & .002 & .384 \\
\hline Teknik Pemb.Kooperatif & 1896.059 & 1 & 1896.059 & 39.380 & .000 & .663 \\
$*$ Berpikir Kritis & & & & & & \\
\hline Error & 962.948 & 20 & 48.147 & & & \\
\hline Total & 123197.867 & 24 & & & & \\
\hline Corrected Total & 3725.674 & 23 & & & & \\
\hline
\end{tabular}

a. $\quad$ R Squared $=.742($ Adjusted R Squared $=.703$ )

\section{Interpretasi Data:}

\section{Pengaruh Utama (Main Effect)}

$F_{\text {hitung }}($ Teknik Pembelajaran Kooperatif) $=$ 5.539 dengan $\mathrm{P}$-value $=0.029<0.05$ yang berarti bahwa $\mathrm{H}_{0}$ ditolak. Dengan demikian dapat disimpulkan bahwa Teknik Pembelajaran Kooperatif pembelajaran 
Pengaruh Teknik Cooperative Learning Dan

Berpikir Kritis Terhadap Hasil Belajar IPS

Heru Youno

Kooperatif berpengaruh terhadap hasil belajar IPS.

$F_{\text {hitung }}($ Berpikir Kritis $)=12.462$ dengan Pvalue $=0.02<0.05$ yang berarti bahwa $\mathrm{H}_{\mathrm{o}}$ ditolak. Dengan demikian dapat disimpulkan bahwa kemampuan berpikir kritis siswa berpengaruh terhadap hasil belajar IPS

\section{Pengruh Interaksi (interaction effect)}

$F_{\text {hitung }}$ (Teknik Pembelajaran Kooperatif dan Berpikir Kritis) $=39.380$ dengan P-value
$=0.000<0.05$ yang berarti bahwa $\mathrm{H}_{\mathrm{o}}$ ditolak Dengan demikian dapat disimpulkan bahwa ada pengaruh interaksi yang sangat signifikan antara Teknik Pembelajaran Kooperatif dan kemampuan berpikir kritis terhadap hasil belajar IPS.

Pengujian hipotesis selanjutnya adalah dengan menggunakan Uji tukey adapun hasil uji tukey dapat dilihat pada table berikut:

\begin{tabular}{|c|c|c|c|}
\hline $\begin{array}{c}\text { Kelompok Yang } \\
\text { Dibandingkan }\end{array}$ & $\begin{array}{c}\text { Harga Pembeda } \\
\text { Rata-rata }\end{array}$ & $\begin{array}{c}\text { Harga tabel } \\
\alpha=0,05\end{array}$ & Kesimpulan \\
\hline $\mathrm{A} 1 \mathrm{~B} 1$ & 3,33 & 3.08 & Signifikan \\
\hline A1B1 dan A2B1 & 12.22 & 4,90 & Signifikan \\
\hline $\mathrm{A} 1 \mathrm{~B} 2$ dan $\mathrm{A} 2 \mathrm{~B} 2$ & 5,55 & 4,90 & Signifikan \\
\hline
\end{tabular}

\section{PEMBAHASAN}

Berdasarkan hasil pengujian hipotesis terlihat bahwa keempat hipotesis yang diajukan pada penelitian ini telah berhasil menolak hipotesis nol, rincian hasil hipotesis tersebut sebagai berikut.

Pertama, hasil uji hipotesis pertama berdasar hasil analisis varian dua jalur didapat harga $F_{\text {hitung }}=5.539$ dengan $\mathrm{P}$-value $=0.029<$ 0.05 yang berarti bahwa $\mathrm{H}_{\mathrm{o}}$ ditolak. Berdasarkan pengujian hipotesis di atas dapat disimpulkan bahwa terdapat perbedaan hasil belajar IPS antara siswa yang mengikuti teknik pembelajaran kooperatif dengan teknik NHT dan TGT pada siswa kelas V SDN Ciwaruga 1. Skor rata-rata hasil belajar IPS siswa yang mengikuti teknik pembelajaran $N H T=73.88$ mengikuti teknik pembelajaran $T G T=67.22$. Sehingga secara keseluruhan, hasil belajar IPS siswa yang mengikuti pelajaran dengan teknik pembelajaran NHT lebih baik dari pada teknik pembelajaran $T G T$.

Hasil uji hipotesis tersebut menunjukkan bahwa teknik pembelajaran NHT lebih unggul dalam meningkatkan hasil belajar IPS dari pada teknik pembelajaran $T G T$.

Kedua, hasil uji hipotesis ketiga yaitu perhitungan uji tukey berhasil Ho ditolak dan $\mathrm{H} 1$ diterima dinamna nilai $\mathrm{q}_{\mathrm{o}}=12.22>\mathrm{q}_{\mathrm{t}}=$ 4,90. Ini berarti bahwa untuk siswa yang memiliki kemampuan berpikir kritis tinggi, terdapat perbedaan hasil belajar IPS antara siswa yang mengikuti teknik pembelajaran NHT dengan siswa yang mengikuti teknik 
pembelajaran TGT pada siswa kelas V SDN Ciwaruga $1 \mathrm{Kec}$. Parongpong. Skor rata-rata hasil belajar IPS siswa yang memiliki kemampuan berpikir kritis tinggi yang mengikuti pembelajaran dengan teknik pembelajaran $N H T=87.77$ dan skor rata-rata hasil belajar IPS siswa yang mengikuti pembelajaran dengan teknik pembelajaran $T G T=63.33$, sehingga dapat disimpulkan bahwa untuk siswa yang memiliki kemampuan berpikir kritis tinggi, hasil belajar IPS siswa yang mengikuti pembelajaran dengan teknik pembelajaran NHT lebih baik daripada siswa yang mengikuti pembelajaran dengan teknik pembelajaran $T G T$ pada siswa kelas V SDN Ciwaruga 1 Kec. Parongpong.

Ketiga, hasil uji hipotesis keempat yaitu perhitung uji tukey berhasil Ho ditolak dan $\mathrm{H} 1$ diterima dinamana nilai $\mathrm{q}_{\mathrm{o}}=5,55>\mathrm{q}_{\mathrm{t}}=4,90$. Ini berarti bahwa untuk siswa yang memiliki kemampuan berpikir kritis rendah, terdapat perbedaan hasil belajar IPS antara siswa yang mengikuti pembelajaran dengan teknik pembelajaran NHT dengan siswa yang mengikuti pembelajaran dengan teknik pembelajaran $T G T$ pada siswa kelas V SDN Ciwaruga $1 \mathrm{Kec}$. Parongpong. Skor rata-rata hasil belajar IPS siswa yang memiliki kemampuan berpikir kritis rendah yang mengikuti pembelajaran dengan teknik pembelajaran $N H T=60.00$ dan skor rata-rata hasil belajar IPS siswa yang mengikuti pembelajaran dengan teknik pembelajaran $T G T=71.11$ sehingga dapat disimpulkan bahwa untuk siswa yang memiliki kemampuan berpikir kritis rendah, hasil belajar IPS siswa yang mengikuti pembelajaran teknik pembelajaran $T G T$ lebih baik daripada siswa yang mengikuti pembelajaran dengan teknik pembelajaran $N H T$ pada siswa kelas V SDN Ciwaruga 1 Kec. Parongpong.

Keempat, hasil uji hipotesis kedua, dari pengolahan data melalui SPSS diperoleh harga $\mathrm{F}_{\text {hitung }}=39.380$ dengan $\mathrm{P}$-value $=0.000<0.05$ yang berarti bahwa $\mathrm{H}_{\mathrm{o}}$ ditolak.. Ini berarti terdapat pengaruh interaksi antara Teknik Pembelajaran Kooperatif (NHT dan $T G T)$ dan kemampuan berpikir kritis terhadap hasil belajar IPS siswa kelas V SDN Ciwaruga 1 Kec. Parongpong. Untuk siswa yang memiliki kemampuan berpikir kritis tinggi, skor ratarata hasil belajar IPS siswa yang mengikuti pembelajaran dengan teknik pembelajaran $N H T=87.77$ dan skor rata-rata hasil belajar IPS siswa yang mengikuti pembelajaran dengan teknik pembelajaran $T G T=63.33$ sehingga dapat disimpulkan bahwa untuk siswa yang memiliki kemampuan berpikir kritis tinggi, hasil belajar IPS siswa yang mengikuti pembelajaran dengan teknik pembelajaran NHT lebih baik daripada siswa yang mengikuti pembelajaran dengan teknik pembelajaran $T G T$. 
Pengaruh Teknik Cooperative Learning Dan

Berpikir Kritis Terhadap Hasil Belajar IPS

Heru Youno

Selanjutnya, untuk siswa yang memiliki kemampuan berpikir kritis rendah, skor ratarata hasil belajar IPS siswa yang mengikuti pembelajaran dengan teknik pembelajaran $N H T=60.00$ dan skor rata-rata hasil belajar IPS yang mengikuti pembelajaran dengan teknik pembelajaran $T G T=71.11$, sehingga hasil belajar IPS siswa yang mengikuti pembelajaran dengan teknik pembelajaran $T G T$ lebih baik daripada siswa yang mengikuti pembelajaran dengan teknik pembelajaran NHT.

\section{SIMPULAN}

Berdasarkan analisis data dan pembahasan seperti yang telah dipaparkan pada bagian sebelumnya, ditemukan beberapa hal sebagai berikut. (1) Ada perbedaan hasil belajar IPS antara siswa yang mengikuti pelajaran dengan teknik pembelajaran $N H T$ dan siswa yang belajar dengan teknik pembelajaran $T G T$ pada kelas V SDN Ciwaruga 1 Kec. Parongpong. Hasil belajar IPS siswa yang mengikuti pelajaran dengan teknik pembelajaran $N H T$ lebih baik daripada hasil belajar IPS siswa yang mengikuti pelajaran dengan teknik pembelajaran TGT. (2) Ada pengaruh interaksi antara Teknik Pembelajaran Kooperatif (Teknik Pembelajaran NHT dan teknik pembelajaran TGT) dengan motivasi berprestasi terhadap hasil belajar IPS siswa kelas V SDN Ciwaruga 1 Kec. Parongpong.
Untuk siswa yang memiliki kemampuan berpikir kritis tinggi, hasil belajar IPS siswa yang mengikuti pelajaran dengan teknik pembelajaran NHT lebih baik daripada teknik pembelajaran TGT. Sebaliknya, untuk siswa yang memiliki kemampuan berpikir kritis rendah, hasil belajar IPS siswa yang mengikuti pelajaran dengan teknik pembelajaran $T G T$ lebih baik daripada Teknik Pembelajaran NHT. (3). Untuk siswa yang memiliki kemampuan berpikir kritis tinggi, ada perbedaan hasil belajar IPS antara siswa yang mengikuti pelajaran dengan Teknik Pembelajaran NHT dan siswa yang mengikuti pelajaran dengan teknik pembelajaran $T G T$ pada siswa kelas $\mathrm{V}$ SDN Ciwaruga 1 Kec. Parongpong. Hasil belajar siswa yang memiliki kemampuan berpikir kritis tinggi yang mengikuti pelajaran dengan Teknik Pembelajaran NHT lebih baik daripada siswa yang mengikuti pelajaran dengan teknik pembelajaran TGT. (4) Untuk siswa yang memiliki kemampuan berpikir kritis rendah, ada perbedaan hasil belajar IPS antara siswa yang mengikuti pelajaran dengan teknik pembelajaran NHT dan siswa yang mengikuti pelajaran dengan teknik pembelajaran $T G T$ pada siswa kelas V SDN Ciwaruga $1 \mathrm{Kec}$. Parongpong. Hasil belajar siswa yang memiliki kemampuan berpikir kritis rendah yang mengikuti pelajaran dengan teknik pembelajaran $T G T$ lebih baik daripada 
siswa yang mengikuti pelajaran dengan teknik pembelajaran NHT.

Berdasarkan temuan diatas maka penelitian ini menimbulkan beberapa implikasi yaitu :

Pertama, penelitian ini menemukan bahwa secara keseluruhan hasil belajar IPS siswa yang mengikuti pelajaran dengan menggunakan teknik pembelajaran NHT dalam pembelajaran IPS lebih baik daripada hasil belajar IPS siswa yang mengikuti pelajaran dengan menggunakan teknik pembelajaran TGT. Temuan penelitian ini mengandung implikasi pentingnya mempertimbangkan penerapan teknik pembelajaran NHT dalam pembelajaran untuk meningkatkan hasil belajar IPS. Langkah pembelajaran yang diterapkan dalam teknik pembelajaran $N H T$ memberikan manfaat yang besar baik bagi guru maupun siswa.

Kedua, jika kemampuan berpikir kritis dipertimbangkan dalam penggunaan teknik pembelajaran NHT, ternyata teknik pembelajaran tersebut memberikan hasil yang lebih baik pada mereka yang memiliki kemampuan berpikir kritis tinggi. Sementara untuk mereka yang memiliki kemampuan berpikir kritis rendah, teknik pembelajaran TGT memberikan hasil yang lebih baik.

Temuan ini memiliki implikasi bahwa dalam menerapkan teknik pembelajaran $N H T$ hendaknya diperhatikan perbedaan kemampuan berpikir kritis siswa sehingga pengelolaan kelas bisa optimal. teknik pembelajaran NHT lebih baik diterapkan pada siswa yang memiliki kemampuan berpikir kritis tinggi. Sedangkan teknik pembelajaran $T G T$ lebih baik diterapkan pada siswa yang memiliki kemampuan berpikir kritis rendah.

Beberapa saran yang dapat dikemukakan terkait dengan hasil penelitian ini tidak terbatas pada pembelajaran tema yang dieksperimenkan, melainkan dapat diterapkan pada tema-tema yang lain, bahkan pada mata pelajaran lainnya, asalkan guru mampu menghimpun tema/permasalahanpermasalahan kontekstual yang dapat diselesaikan dengan menggunakan pengetahuan informal siswa. Beberapa saran yang perlu dilakukan antara lain: 1) Upaya untuk Menerapkan teknik pembelajaran NHT dalam Pembelajaran IPS. 2) Upaya untuk menyusun bahan ajar sebagai pendukung pembelajaran kooperatif. 3) Upaya Menerapkan teknik pembelajaran $T G T$ dalam Pembelajaran IPS.

\section{DAFTAR RUJUKAN}

Depdiknas. 2007. Dirjen Manajemen Pendidikan Dasar dan Menengah Direktorat Pembinaan TK dan SD, Pedoman penyuunan KTSP SD. Jakarta: Badan Standar Nsional Pendidikan.

Desmita. 2011. Psikologi Perkembangan Peserta Didik. Bandung : PT. Remaja Rosdakarya 
Pengaruh Teknik Cooperative Learning Dan

Berpikir Kritis Terhadap Hasil Belajar IPS

Heru Youno

Faiz, Fahruddin. 2012. Thinking Skill

Suprijono, Agus, 2011. Cooperative Learning Pengantar Menuju Berpikir Kritis. Yogyakarta: SUKA-Press

Fisher, Alec. 2004. Berpikir kritis: sebuah pengantar. Jakarta: Erlangga

Hamalik, Oemar. 2002. Psikologi Belajar dan Mengajar. Bandung: Sinar Baru Algesindo

Isjoni, 2009. Cooperative Learning Efektivitas Pembelajaran Kelompok. Bandung: Alfabeta

Kristanty, Theresia. 2009. Evaluasi Pembelajaran Bagi Mahasiswa PAUD dan DIKDAS. Jakarta: PGSD FKIP UNJ.

Nur, Mohamad. 2011. Model Pembelajaran Kooperatif. Surabaya: Pusat Sains dan Matematika Sekolah UNESA

Nurhadi, dkk, 2003. Pembelajaran Kontekstual dan Penerapannya dalam $K B K$. Malang: Universitas Negeri Malang.

Rusman. 2010. Model-Model Pembelajaran mengembangkan Profesionalisme Guru. Jakarta: Rajawali Pers.

Sagala, Syaiful. 2010. Konsep dan Makna Pembelajaran. Bandung: Alfabeta.

Slavin, Robert E. 2010. Cooperative Learning. Teori, Riset, dan Praktik. Diterjemahkan oleh Narulita Yusron. Bandung: Nusa Media.

Sudjana, Nana. 2009. Penilaian Hasil Proses Belajar Mengajar.Bandung : Remaja Rosdakarya.

Sumantri, M.N, 2001. Menggagas Pembaharuan Pendidikan IPS. Bandung: PPS-UPI dan PT. Remadja Rosda Karya. 